\title{
Research of the Chemical Heterogeneity during Crystallization for AlCu4MgMn Alloy and the Possibility of its Elimination.
}

\section{Viktorie Weiss}

The Institute of Technology and Business in České Budějovice, Okružní 517/10, 37001 České Budějovice. E-mail: 19638@mail.vstecb.cz

Crystal segregation is taken as chemical heterogeneity under the micro-scale and it develops during the crystallization process. Alloy crystallization does not take place under a particular temperature, as it happens in the case of pure metals, but it runs under a certain temperature interval. When cooling the melt, various places start development among dendritic cells which differ in their chemical composition. Crystal segregation can be generally defined as chemical heterogeneity developing during the alloy crystallization process, and it can be either en-riched or in contrast depleted with alloying elements and impurities, which are unevenly segregating over the en-tire dendritic surface. In the central part of the dendritic cells there is an alloy, which is depleted with alloying elements, while the edge areas of dendritic cells and interdendrite space present higher concentration of alloying elements. This concentration shows a hyperbolic development; when the central part of dendritic cells area has the lowest alloying elements concentration, while the edge part of a dendritic tree and the interdendrite space show the maximum concentration. The distance between two main axes of dendritic cells is affected by the temperature interval running between the liquid and solid phase of the chosen alloy, as well as by melt cooling rate and temperature gradient during the solidification phase. The shorter distance between the axes of dendritic cells appears under faster cooling, which allows very fast heat dissipation and creates very fine structure of the resulting alloy. The longer distance between the main axes of dendritic cells stimulates greater segregation appearing under slow melt cooling.

Crystal segregation formation of aluminum alloys enriched with alloying elements and impurities cannot be prevented, only its extension can be regulated and it can be suppressed with the correct choice of heat treatment parameters. To suppress the crystal segregation the casts should undergo heat treatment which is called homogenization annealing.

Keywords: homogenization annealing, $\mathrm{AlCu} 4 \mathrm{MgMn}$ alloy, crystal segregation, EDX analysis, image analysis

\section{References}

[1] MICHNA, Š., LUKÁČ, I. et al. (2007). Aluminium materials and technologies from A to Z, Printed by Adin, s.r.o., Prešov. ISBN 978-80-8244-18-8.

[2] MICHNA, Š., NOVÁ, I. (2008). Technologie a zpracování kovových materiálů, Adin, s.r.o., Prešo, ISBN 978-8089244-38-6.

[3] VAJSOVÁ, V. (2011). Optimization of homogenizing annealing for Al-Zn5.5-Mg2.5-Cu1.5 alloy, Metallurgist, Volume 54, Issue 9, ISSN 0026 - 0894.

[4] VAJSOVÁ, V., MICHNA, Š. (2010). Optimization of AlZn5.5Mg2.5Cu1.5, Alloy Homogenizing Annealing, Metallofizika i noveishie tekhnologii, Volume 32, No. 7, ISSN 1024 - 1809.

[5] WEISS, V., STŘIHAVKOVÁ, E. (2012). Influence of the homogenization annealing on microstructure and mechanical properties of AlZn5,5Mg2,5Cu1,5 alloy, Manufacturing Technology, Vol. 12, No, 13, ISSN 1213 -2489.

[6] STřIHAVKOVA, E., WEISS, V. (2012) The Identification of the struktures new type Al-Si-Mg Ca alloys with different Ca kontent using of the color metallography, Manufacturing Technology, Vol. 12, No, 13, ISSN 1213 2489.

[7] WEISS, V. (2012). Hodnoceni vlivu teploty a doby homogenizačního žíhaní slitiny AlCu4MgMn z hlediska mikrostruktury, obrazové analýzy a metody EDX, Strojírenská technologie, ročník XVII, ISSN 1211 - 4162.

[8] WEISS, V., STŘIHAVKOVÁ, E. (2011). Optimalizace homogenizačního žíhaní slitiny AlCu4MgMn, Strojírenská technologie, ročník XVI, ISSN 1211 - 4162.

[9] WEISS, V. (2012). Vliv slévárenských forem na kvalitu povrchu a strukturu slitiny AlZn5,5Mg2,5Cu1,5, Strojírenská technologie, ročník XVII, č. 1 a 2, 2012, ISSN 1211 - 4162.

[10]WEISS, V. (2012). Hodnoceni vlivu teploty a doby homogenizačního žíhaní slitiny AlCu4MgMn z hlediska mikrostruktury, obrazové analýzy a metody EDX, Strojirenská technologie, ročník XVII, ISSN 1211 - 4162. 
[11]MICHNA, Š., NÁPRSTKOVÁ, N. (2012). The use of fractography in the analysis of cracking after formed workpiece blank mechanical machining from the AlCuSnBi alloy, Manufacturing Technology, Vol.12, No 13. ISSN $1213-2489$.

[12] NOVÁK, M. (2013). Differences at the Surface Roughness by the ELID and Grinding Technology. In Manufacturing Technology, roč. 13, No. 2, UJEP: Ústí n. Labem. 210 - 215 pp. ISSN 1213-2489.

\section{Paper number: M201659}

Copyright $\odot$ 2016. Published by Manufacturing Technology. All rights reserved. 